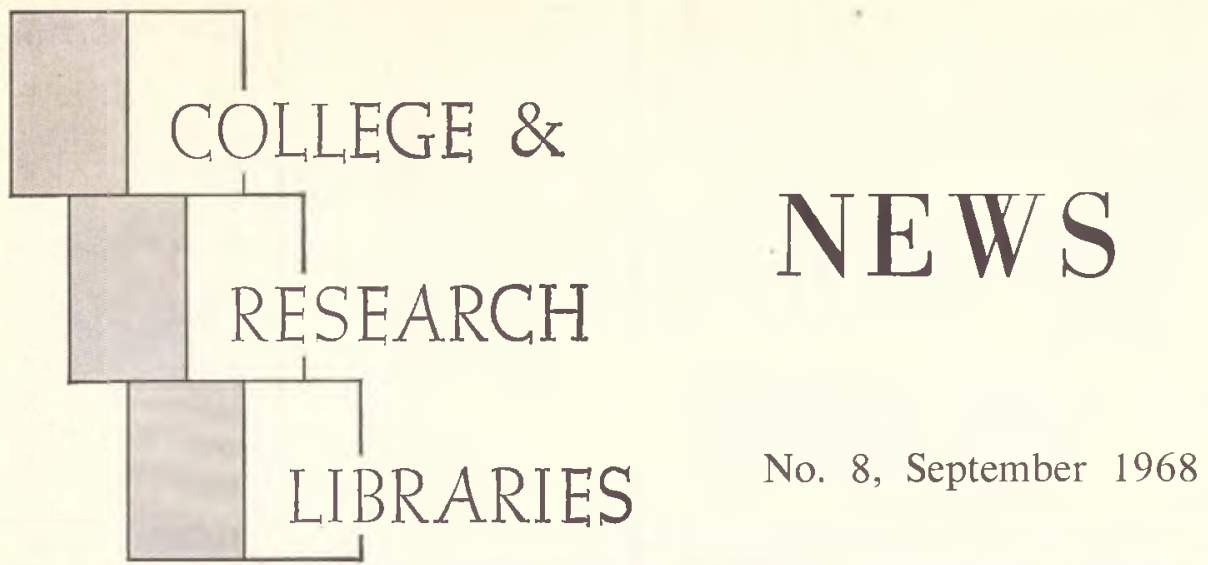

ACRL News Issue (A) of College \& Research Libraries, Vol. 29, No. 5

\title{
ACRL Grants Program
}

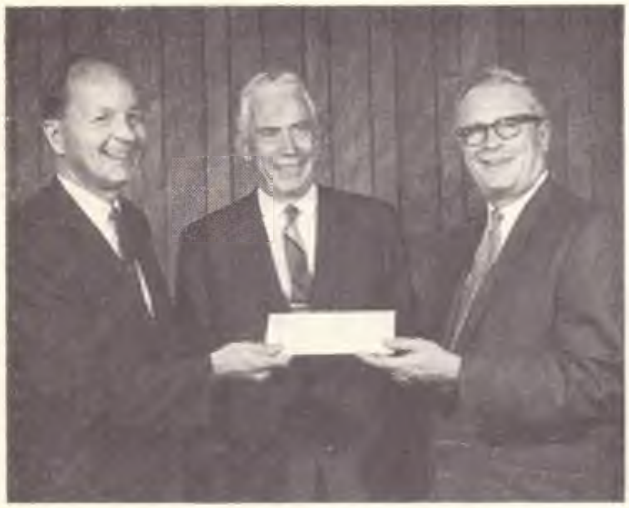

The ACRL Grants Program, now in its fourteenth year of service to privately endowed, four-year, undergraduate institutions, will continue support from the United States Steel Foundation, the Library Bureau Remington Office Systems Division of Sperry Rand Corporation; H. IV. Wilson Foundation, the Olin Mathieson Charitable Trust, TIME Incorporated, Pitney Bowes, Inc. and the McGraw-Hill Publishing Company.

As in past years, the Committee on Grants will consider applications for the improvement and development of library collections from privately supported institutions whose curriculum incorporates a four-year program of undergraduate instruction. Applications for items or projects which would be a normal part of the academic library budget will not be given consideration in view of the large number of applications received each year. It should be re-
Shown at a luncheon in Chicago where United States Steel Foundation checks were distributed to educators are: (Left to right) H. Vail Deale, chairman of the Committee on Grants of ACRL and librarian at Beloit College (Beloit, Wis.); Vernard M. Christensen, general superintendent of the Elgin, Joliet, and Eastern Railuay Company; and James $T$. Hosey, director of programing for the United. States Steel Foundation.

membered that the grants are primarily for the improvement and development of college undergraduate collections in ways in which the institution itself would not, or cannot, give assistance. The Committee will continue its support of the federal program of basic grants (under the Higher Education Act 1965) by considering requests to employ consultant help.

A substantial contribution has again been received from Library Bureau/Remington Rand, for the purchase of wood furniture and equipment. The same form should be used to request furniture and equipment grants as for the monetary grants.

Application forms are being mailed early in September to librarians of all eligible institutions, as listed in the current U.S. Office of Education, Directory Part $I I I$, Higher Education. Application forms must be returned to the ACRL Office no later than October 9.

Requests for the support of research or bibliographical projects from individual librarians may also be submitted for consideration of the Committee. Such requests will be given particular consideration if the research or bibliographic activity would result in something ben- 

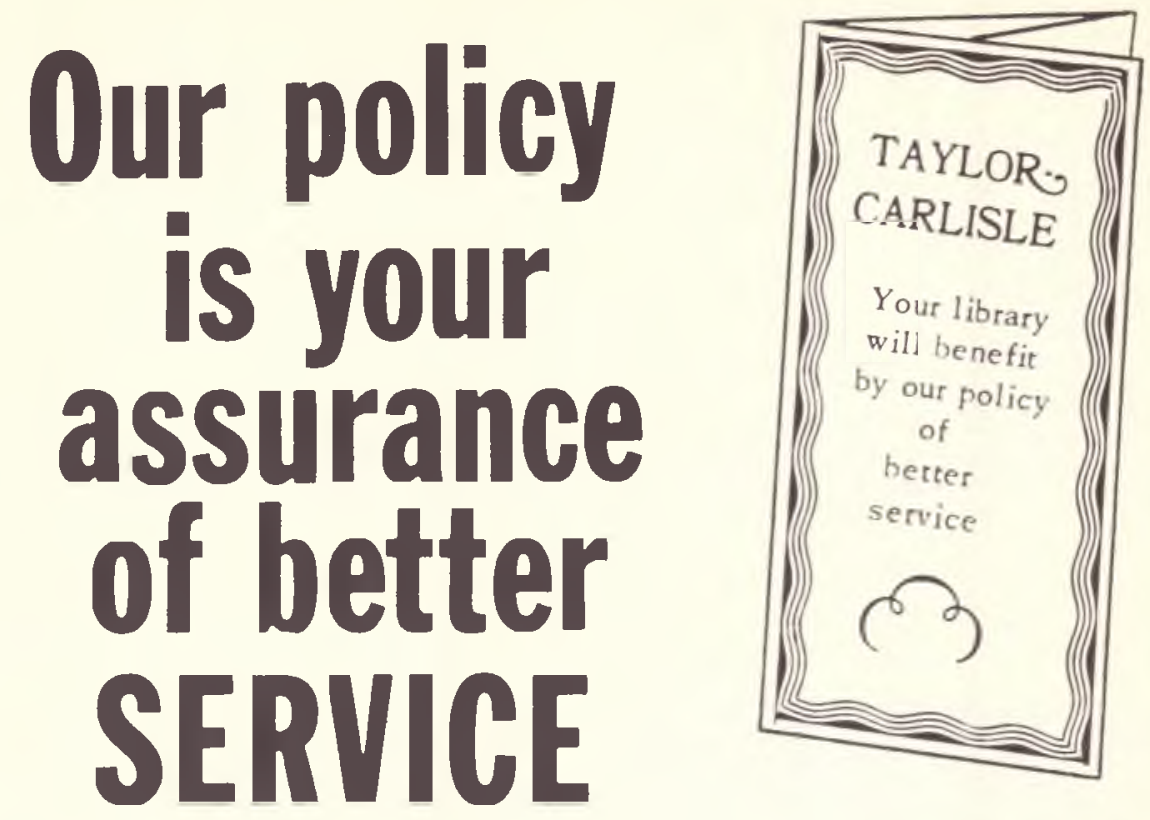

for a quarter of a century, Taylor-Carlisle's policy has been to offer its clientele the finest service possible.

This policy is supported by a huge inventory conveniently at hand in our own warehouses...

... by having competent, efficient personnel...

... and experienced, progressive management.

Better service is our policy.

Send for our brochure and terms.

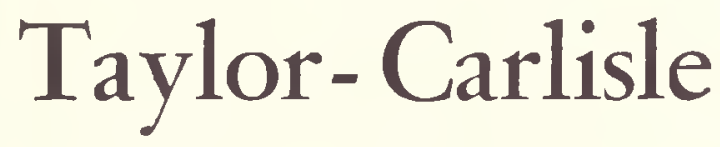

NEW YORK: 115 East 23rd Street, New York, N.Y. 10010 FLORIDA: Winter Park Mall, Winter Park, Florida TEXAS: 1 Shell Plaza, Houston (opening soon)

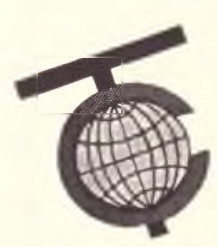


eficial to academic libraries. A request for the proper form should be addressed to the ACRL office.

Members of the ACRL Committee on Grants are: H. Vail Deale, chairman; Humphrey G. Bousfield, consultant; Johnnie E. Givens, Mrs. Virginia Lacy Jones, Rev. Vincent R. Negherbon, Mrs. Jessie Carney Smith, Donald E. Vincent, and David Kaser (ex officio). Any further inquiries should be sent to the Executive Secretary, Association of College and Research Libraries, 50 East Huron Street, Chicago, Illinois 60611 .

\section{AUGMENTED CRL EDITORIAL STAFF}

David Doerrer, assistant circulation librarian, Cornell University, has been named News editor of CRL. Mr. Doerrer will assist David Kaser in the preparation of the monthly $C R L$ News issues. He holds the AB and MSLS degrees from Syracuse University, and is presently writing his thesis for an MA in American history at Syracuse. $\mathrm{He}$ is a former contributor to $C R L$

Mrs. Betty Swint of the Joint University Libraries, Nashville, continues as assistant editor of the bimonthly journal.

Mary Falvey, ACRL publications officer since 1961, on Sept. 1 became managing editor of the Central Production Unit at ALA headquarters. This is a new unit which will be responsible for the production of five journals, six newsletters and other printing and publications for ALA divisions.

\section{MARGARET MANN CITATION}

An annual citation, awarded by the Cataloging and Classification Section of the Resources and Technical Services Division, made to a cataloger and/or classifier, not necessarily an American, for his outstanding professional achievement in the areas of cataloging and classification, either through publication of significant professional literature, participation in professional cataloging associations, introduction of new techniques of recognized importance, or outstanding work in the area of teaching within the past five years.

Deadline for nominations, Dec. 1. Send nominations with resume of achievement on which nomination is based, in triplicate, to the committee chairman-Mrs. Benjamin A. Custer, 9305 Twentieth Avenue, Adelphi, Maryland 20783.

\section{ACRL Membership}

Tuly 31,1968

12,604

July 31,1967

11,915

July 31, 1966

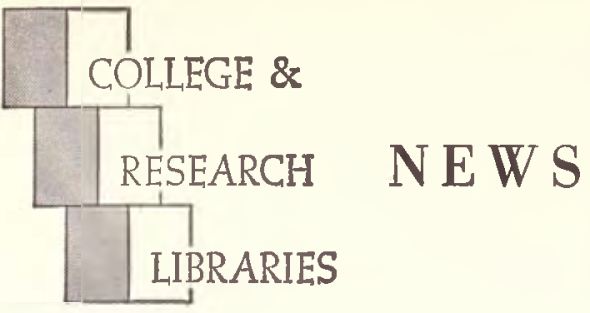

ACRL News Issue of College \& Research Libraries

Editor, David Kaser, Cornell University Libraries, Ithaca, N.Y. 14850.

Managing Editor, Mary Falvey, 50 E. Huron St., Chicago 60611.

News Editor, David Doerrer, Cornell University Libraries, Ithaca, N.Y. 14850.

Editorial Board: John M. DAwson, University of Delaware; Gustave A. Harrer, University of Florida; Samuel Rothstern, University of British Columbia; JAMES E. SkIPPER, University of California, Berkeley; Nomman E. Tanis, Kansas State College of Pittsburg; Mauruce F. Tauner, Columbia University; Emeen Thorston, Oberlin College.

ACRL Officers, 1968/69: President, David Kaser; Chairman, College Libraries Section, Evan Ira Farber; Junior College Libraries Section, Shirley A. Edsall; Rare Books Section, J. M. Edelstein; Subject Specialists Section, Thomas D. Gillies; Agriculture and Biological Sciences Subsection, Louise Darling; Art Subsection, Herbert G. Scherer; Law and Political Science Subsection, Morris L. Cohen; Slavic and East European Subsection, Dmytro M. Shtohryn; University Libraries Section, G. F. Shepherd.

News from the Field, Personnel profiles and notes, classified advertising, official matter of ACRL, and other material of a timely nature is published in the News issues of College \& Research Libraries.

Inclusion of an article or advertisement in $C R L$ does not constitute official endorsement by ACRL or ALA. Production and Advertising and Circulation office: 50 E. Huron St., Chicago, 111. 60611. Change of address and orders for subscriptions should be addressed to College \& Research Libraries, for receipt at the above address, at least two months before the publication date of the effective issue.

Subscription to $C R L$ is included in membership dues to $A C R L$ of $\$ 6$ or more; other subscriptions to $C R L$ are $\$ 10$ per year. Neither subscriptions nor memberships include miscellaneous unscheduled supplements, which are available by purchase only. Retroactive subscriptions are not accepted. Single journal copies are available at $\$ 1.50$ each and News issues at $\$ 1.00$ each from ALA Publishing Department.

Indexed in Library Literature. Abstracted in Library Science Abstracts. Book reviews indexed in Book Review Index.

College \& Research Libraries is the official journal of the Association of College and Research Libraries, a division of the American Library Association; and is published seventeen times per year-bi-monthly as a technical journal with 11 monthly News issues, combining July-August - at 1201-05 Bluff St., Fulton, Mo. 65251

Second-class postage paid at Fulton, Mo. 